\title{
Socio-economic development, level of urbanization and consumption of selected food products as factors in the prevalence of overweight and obesity among youths and young adults in Poland
}

\author{
Maria Klatka ${ }^{1, A, E-F \oplus}$, Ewa Zienkiewicz ${ }^{2, A, C-D, F}$, Witold Kołłątaj ${ }^{1, E-F} \oplus$, Tadeusz Zienkiewicz ${ }^{3, B-C, F} \oplus$, \\ Barbara Kołłątaj ${ }^{4, E-F(}$ \\ ${ }^{1}$ Department of Paediatric Endocrinology and Diabetology, Medical University, Lublin, Poland \\ ${ }^{2}$ Department of Paediatric Neurology, Faculty of Paediatrics, Medical University, Lublin, Poland \\ ${ }^{3}$ Faculty of Economics, Maria Curie-Skłodowska University, Lublin, Poland \\ ${ }^{4}$ Chair and Department of Epidemiology, Medical University, Lublin, Poland \\ A - Research concept and design, B - Collection and/or assembly of data, C - Data analysis and interpretation, \\ $D$ - Writing the article, E-Critical revision of the article, F-Final approval of article
}

\begin{abstract}
Klatka M, Zienkiewicz E, Kołłątaj W, Zienkiewicz T, Kołłątaj B. Socio-economic development, level of urbanization and consumption of selected food products as factors in the prevalence of overweight and obesity among youths and young adults in Poland. Ann Agric Environ Med. 2020; 27(1): 139-145. doi: 10.26444/aaem/112373
\end{abstract}

\begin{abstract}
Introduction and objective. Obesity and overweight among teenagers and young adults pose serious problems for the Polish health care system. The aim of this study was to assess the relationships between the prevalence of overweight and obesity and the level of urbanization, consumption of selected food products and socio-economic development in the provinces in Poland.

Materials and method. The material used in this study is based on data published by the Central Statistics Office (GUS) for population, components of the Human Development Index (HDI), urbanization level (URBI), average monthly consumption of selected food products per person, and the percentage of obese and overweight people in the Polish provinces. The prevalence of overweight and obesity in all 16 provinces was analysed in the context of the URBI, HDI, and the average monthly consumption of selected food products.

Results. There was no a statistically significant correlation between the number of overweight and obesity cases and the levels of HDI and URBI. The negative correlations were found between the consumption of sugar and URBI $(-0,710, p=0.002)$, bread and grain product consumption $(-0.642 ; p=0.007)$ and fresh milk consumption $(-0.594 ; p=0.015)$. Fish consumption correlated with URBI at a moderate level $(0.550 ; p=0.027)$. The consumption of oils and fats strongly correlated with $\mathrm{HDI}$ $(-0.788 ; p<0,001)$. In the group of overweight woman, a moderate negative correlation was noted $(-0.511 ; p=0.043)$ in cheese and curd consumption.

Conclusions. The high level of economic development and urbanization have no direct impact on the prevalence of overweight and obesity in Poland. The results of the study indicate existing dependencies of the consumption of some of selected products with respect to the level of urbanization.
\end{abstract}

\section{- Key words}

obesity, urbanization, adolescents, socio-economic development

\section{INTRODUCTION}

Obesity in children and adolescents is a public health issue in many countries and is the result of a chronic imbalance between the energy supplied from food versus the energy required for movement, vital functions and thermogenesis. Obesity is treated as an important risk factor in the development of chronic non-communicable diseases, which contribute to a reduced quality of life and life expectancy. As a multifactorial disease, in addition to genetics, which can explain up to $30-40 \%$ of obesity cases, lifestyle habits,

Address for correspondence: Tadeusz Zienkiewicz, Faculty of Economics, Poland Maria Curie-Skłodowska University, Lublin, Poland

E-mail: tzienkiewicz@op.pl

Received: 18.12.2018; accepted: 05.09.2019; first published: 23.09.2019 family, social, and environmental contexts can be predictors of weight gain $[1,2,3]$.

Among the environmental and behavioural factors, the most important seem to be the following: poor diet, little physical activity, a sedentary lifestyle, and sleep deficiency, which is the reason for increasing ghrelin serum levels and decreasing leptin hormone levels, leading to an increase in appetite and consequent weight gain [4]. It is notable that among the environmental factors affecting increasing obesity rates, some of them are significant: the advertising of food products, eating habits, availability of foods rich in monosaccharides and disaccharides, and finally, cultural changes $[5,6,7]$. Advertisements suggest an intake of highly processed foods high in sugars and disaccharides (sweetened drinks, chocolate bars, drinking chocolate, ice cream, 
sweetened yogurts, etc.). In the Polish psyche, sweets are treated as a reward and a source of pleasure $[8,9]$.

Many factors for increased food consumption can be explained from the make-up of society and, in particular, the way in which social groups are organized. Undoubtedly, a higher density of fast food restaurants and convenience stores located close to residential areas, usually offer the same and highly caloric food [10]. Area-based or neighbourhood socio-economic deprivation is also associated with physical inactivity, poor diet and increasing risk of obesity $[11,12]$.

Obesity poses a big and real threat to the health status of individuals as well as to the health status of populations. The economic consequences of obesity are both evident and negative $[13,14]$. Overweight and obesity in children and adolescents increase the risk of breast, colon and prostate cancer, heart disease, hypertension, Type 2 diabetes and metabolic syndrome, as well as kidney and bladder cancer $[15$, 16]. The International Diabetes Federation (IDF) identifies that untreated obesity and hypertension are components of metabolic syndrome and raised mortality $[17,18]$.

Over the past several decades, obesity has become a major global epidemic. In 1997, the World Health Organization (WHO) officially defined obesity as a disease. Since 1980, the number of obese Europeans has almost tripled, and in the United States in 2010, more than two-thirds of adults were overweight and one-third were obese [19].

According to a report by the Polish Central Statistics Office (GUS), "Health status of the population in 2014", more than $62 \%$ of men and $46 \%$ of women had excess body weight. More than $44 \%$ of men were overweight and $18 \%$ were obese. As for women, $30 \%$ were overweight and $16 \%$ were suffering from obesity [20].

The epidemic of obesity in the adult population has been accompanied by a rapid increase in the number of obese children and adolescents. According to research by the National Food and Nutrition Institute (Poland), the percentage of children and adolescents who were overweight and obese in Poland was under 9\% in 1995 and over 11\% in 2000. Studies carried out in 2005-2006 on adolescents aged 11-15 living in Warsaw, revealed that $18 \%$ of boys and $12 \%$ of girls were overweight, and $3 \%$ of them were obese [21].

A study conducted by the National Food and Nutrition Institute in 2010 (the study involved 1,255 children aged 9 living in the Mazowieckie, Podkarpackie, Opolskie, Pomorskie and Wielkopolskie provinces in Poland) suggested that nearly $19 \%$ of girls and over $17 \%$ of boys were overweight and $4 \%$ of girls and more than $6 \%$ of boys were obese. In 2014, the prevalence of abdominal obesity in rural boys and girls was close to $11 \%$ and $9 \%$, respectively [22]. The above data suggest that overweight and obesity rates are escalating. The dynamic growth of overweight and obesity resulting from lifestyle and changes in dietary behaviours of society is also linked to socio-economic changes occurring in individual social groups and countries.

Studies on the impact of socio-economic conditions on the occurrence of obesity in children and adolescents have been undertaken in many countries, but the results are not unequivocal $[23,24,25,26]$. Diversity in the field of socioeconomic development occurs not only between individual ethnic groups but also within groups in countries with a multi-ethnic structure of society. Multi-ethnicity in most cases implies belonging to social groups with diverse religious and socio-economic status. Therefore, socio-cultural diversity and economic status are taken into account by researchers of obesity [27, 28, 29].

The relationship between the level of urbanization and the occurrence of overweight and obesity is also a subject of interest. In this case, the results of the research are also not clear $[30,31,32]$.

To determine the relationship between socio-economic development, the level of urbanization, the consumption of selected food products and the occurrence of overweight and obesity is not a new problem. However, due to the changing living conditions in Poland, the improvement of economic status and changes taking place in the Polish psyche, it is advisable that one continues to assess the phenomenon of obesity and overweight as the effects of multifaceted changes in Polish society.

\section{OBJECTIVE}

The aim of this study was to assess the relationships between the prevalence of overweight and obesity and the level of urbanization, the consumption of selected food products and the socio-economic development within the different provinces in Poland.

\section{MATERIALS AND METHOD}

The material used in this study is based on data published by GUS for population, components of the Human Development Index (HDI), urbanization level, average monthly consumption of selected food products per person and the percentage of people with obesity and overweight in all the Polish provinces. These data reflect the years 2003 $2014[33,34]$. Data on the number of overweight and obese people were taken from the GUS report "Health status of the population in 2014" [20].

In this study, the terms 'adolescents and young adults' were used to describe the group of people aged 15-29.

In order to illustrate the problem of obesity and overweight in Poland in the most appropriate way, the following subgroups within the population of people aged 15-29 years were singled out: female overweight (FOW); female obesity (FOB); male overweight (MOW); male obesity (MOB). Data were taken from the GUS report "Health status of population in Poland in 2014" [20] (Tab. 1).

In order to facilitate the data analysis, all Polish provinces were divided into two groups according to their urbanization levels. Provinces with more than $50 \%$ of inhabitants living in urban areas (urbanization index $>0.50$ ) were defined as urban regions (predominantly urban), while provinces with less than $50 \%$ of inhabitants living in urban areas (urbanization index $<0.50$ ) were defined as rural regions (predominantly rural).

HDI is a synthetic measure that describes the effects of the socio-economic development of countries and regions. This index was introduced for the first time by the United Nations for the purpose of international comparison. A method for its calculation was presented in 1990 by a specialized agency of the United Nations - the United Nations Development Programme, and it is used to compare living conditions $[35,36]$. 
Table 1. Aspects of the prevalence of obesity and overweight in the Polish provinces (2014)

\begin{tabular}{|c|c|c|c|c|c|c|}
\hline \multirow{2}{*}{ Province } & \multirow{2}{*}{ Population [thousand] } & \multicolumn{5}{|c|}{ Subpopulation of $15-29$-year-olds } \\
\hline & & Total [thousand] & MOW [thousand] & MOB [thousand] & FOW [thousand] & FOB [thousand] \\
\hline DLN & 2908.5 & 395.4 & 28.9 & 8.6 & 21.9 & 10.0 \\
\hline KPM & 2090.0 & 341.9 & 53.0 & 14.5 & 22.0 & 6.5 \\
\hline LUB & 2147.7 & 327.3 & 44.0 & 8.5 & 24.8 & 4.8 \\
\hline LBS & 1020.3 & 161.5 & 27.1 & 4.5 & 15.7 & 4.5 \\
\hline MLP & 3368.3 & 464.8 & 75.4 & 5.5 & 13.7 & - \\
\hline MAZ & 5334.5 & 882.6 & 113.5 & 23.3 & 44.8 & 19.0 \\
\hline OPO & 1000.9 & 168.9 & 26.3 & 0.4 & 13.9 & 0.9 \\
\hline PDK & 2129.2 & 431.1 & 56.2 & 12.7 & 20.2 & 5.6 \\
\hline PDL & 1191.9 & 198.3 & 33.9 & 5.7 & 13.5 & - \\
\hline SKL & 4585.9 & 736.7 & 101.1 & 13.1 & 55.3 & 22.7 \\
\hline SWK & 1263.2 & 201.6 & 31.7 & 1.2 & 12.8 & 2.0 \\
\hline WMZ & 1444.0 & 236.0 & 35.9 & 9.9 & 14.9 & 3.3 \\
\hline WLK & 3472.6 & 623.6 & 80.5 & 15.5 & 46.5 & 12.5 \\
\hline ZPM & 1715.4 & 298.0 & 32.0 & 3.3 & 13.8 & 8.1 \\
\hline
\end{tabular}

Source: [33,34]

Provinces: DLN - Dolnoślaskie; KMP - Kujawsko-Pomorskie; LUB - Lubelskie; LBS - Lubuskie; LDZ - Łódzkie; MLP - Małopolskie; MAZ - Mazowieckie; OPO - Opolskie; PDK - Podkarpackie; PDL Podlaskie; POM - Pomorskie; WMZ - Warmińsko-Mazurskie; SKL - Śląskie; SWK - Świętokrzyskie; WKL - Wielkopolskie; ZPM - Zachodniopomorskie.

FOW - Female overweight; FOB - Female obesity; MOW - Male overweight; MOB - Male obesity.

The HDI measures a country's (or a region's) average achievement in three main aspects of human development: longevity, knowledge (education), and a decent standard of living (defined by GDP pc in Purchasing Power Parity, i.e. gross domestic product per capita converted to international dollars using purchasing power parity rates).

To determine the HDI values for Polish provinces, the following indicators were taken into account to describe the situation in the areas under analysis: fixed minimum and maximum values for life expectancy (25/85 years), a total enrolment rate $(0-100 \%)$, reading and writing comprehension (0-100\%), GDP pc in Purchasing Power Parity terms. Provinces were also divided into two groups according to Human Development Index values. In order to divide provinces into well and poorly developed regions, the median value of the HDI (0.7575) was used.

Statistical analysis. The data obtained were presented as mean \pm standard deviation (SD). Parametric statistics, the t-test, and the Pearson correlation were used to analyse the differences in scores between different groups of provinces (urban vs. rural and poorly developed vs. well-developed) and to find the proportional relationships between the number of overweight and obese females and males in the population.

The level of statistical significance was set at $\mathrm{p}<0.05$. Data were analysed using Statistica software, version 8.0.

To avoid ambiguity, the province names/abbreviations were used: DLN: Dolnośląskie; KMP: Kujawsko-Pomorskie; LUB: Lubelskie; LBS: Lubuskie; LDZ: Łódzkie; MLP: Małopolskie; MAZ: Mazowieckie; OPO: Opolskie; PDK: Podkarpackie; PDL: Podlaskie; POM: Pomorskie; WMZ: Warmińsko-mazurskie; SKL: Śląskie; SWK: Świętokrzyskie; WKL: Wielkopolskie; ZPM: Zachodniopomorskie.

In the case of milk (litres) and eggs (units), units of measurement were converted to kilograms/grams.

\section{RESULTS}

In order to conduct comparative studies, data concerning the prevalence of obesity and overweight in males and females 15-29 years of age, were calculated as a percentage of obese and overweight persons of the total population. Data and indicators describing the degree of urbanization (UBRI) and living standards (HDI) in the Polish provinces are shown in Table 2.

Table 2. HDI and URBI index values and data describing the prevalence of overweight and obesity in the study group (15-29-year-olds), by Polish provinces (2104)

\begin{tabular}{lcccccc}
\hline Province & HDI & URBI & MOW [\%] & MOB [\%] & FOW [\%] & FOB [\%] \\
\hline DLN & 0.760 & 0.701 & 0.994 & 0.296 & 0.753 & 0.344 \\
\hline KPM & 0.752 & 0.605 & 2.536 & 0.694 & 1.053 & 0.311 \\
\hline LUB & 0.755 & 0.466 & 2.049 & 0.396 & 1.155 & 0.223 \\
\hline LBS & 0.755 & 0.635 & 2.656 & 0.441 & 1.539 & 0.441 \\
\hline LDZ & 0.752 & 0.640 & 2.472 & 0.711 & 1.605 & 0.048 \\
\hline MLP & 0.765 & 0.492 & 2.238 & 0.163 & 0.407 & - \\
\hline MAZ & 0.781 & 0.646 & 2.128 & 0.437 & 0.840 & 0.356 \\
\hline OPO & 0.756 & 0.523 & 2.628 & 0.040 & 1.389 & 0.090 \\
\hline PDK & 0.755 & 0.414 & 2.640 & 0.596 & 0.949 & 0.263 \\
\hline PDL & 0.761 & 0.604 & 2.844 & 0.478 & 1.133 & - \\
\hline POM & 0.768 & 0.660 & 1.672 & 0.569 & 0.986 & 0.691 \\
\hline SKL & 0.759 & 0.780 & 2.205 & 0.286 & 1.206 & 0.495 \\
\hline SWK & 0.757 & 0.450 & 2.510 & 0.095 & 1.013 & 0.158 \\
\hline WMZ & 0.754 & 0.597 & 2.486 & 0.686 & 1.032 & 0.229 \\
\hline WLK & 0.762 & 0.559 & 2.318 & 0.446 & 1.339 & 0.360 \\
\hline ZPM & 0.758 & 0.688 & 1.865 & 0.192 & 0.804 & 0.472 \\
\hline Sorce: & 1645 & 1960 & $1334]$ & & & \\
\hline
\end{tabular}

Source: own calculations using data from $[33,34]$

Provinces: DLN - Dolnośląskie; KMP - Kujawsko-Pomorskie; LUB - Lubelskie; LBS - Lubuskie; LDZ - Łódzkie; MLP - Małopolskie; MAZ - Mazowieckie;OPO-Opolskie; PDK - Podkarpackie; PDL Podlaskie; POM - Pomorskie; WMZ - Warmińsko-Mazurskie; SKL - Śląskie; SWK-Świętokrzyskie; WKL - Wielkopolskie; ZPM - Zachodniopomorskie.

FOW-Female overweight; FOB - Female obesity; MOW - Male overweight; MOB - Male obesity. 
Table 3. Average monthly consumption of selected food products per person (2014)

\begin{tabular}{|c|c|c|c|c|c|c|c|c|c|c|}
\hline Province & $\begin{array}{l}\text { Bread and Grain } \\
\text { Products [kg] }\end{array}$ & Meat [kg] & Fish [kg] & $\begin{array}{l}\text { Oils and fats } \\
{[\mathrm{kg}]}\end{array}$ & Fruits [kg] & $\begin{array}{l}\text { Vegetables } \\
{[\mathrm{kg}]}\end{array}$ & Sugar [kg] & $\begin{array}{l}\text { Fresh milk* } \\
{[\mathrm{kg}]}\end{array}$ & $\begin{array}{c}\text { Cheese and Curd } \\
{[\mathrm{kg}]}\end{array}$ & $\operatorname{Egs}^{*}[\mathrm{~kg}]$ \\
\hline DLN & 5.84 & 5.15 & 0.31 & 1.28 & 3.71 & 9.08 & 1.02 & 3.14 & 0.94 & 1.20 \\
\hline KPM & 6.38 & 5.77 & 0.37 & 1.27 & 3.32 & 8.83 & 1.19 & 3.59 & 0.74 & 1.20 \\
\hline LUB & 6.91 & 5.38 & 0.31 & 1.22 & 3.82 & 10.17 & 1.47 & 3.65 & 0.78 & 1.35 \\
\hline LBS & 6.05 & 5.66 & 0.31 & 1.30 & 3.62 & 9.11 & 1.10 & 3.56 & 0.81 & 1.19 \\
\hline MLP & 6.41 & 4.92 & 0.29 & 1.15 & 3.37 & 8.88 & 1.48 & 3.69 & 0.85 & 1.23 \\
\hline MAZ & 6.06 & 5.15 & 0.34 & 1.08 & 4.00 & 8.80 & 1.12 & 3.11 & 0.86 & 1.14 \\
\hline OPO & 6.13 & 5.02 & 0.30 & 1.27 & 3.23 & 9.30 & 0.98 & 3.12 & 0.76 & 1.21 \\
\hline PDK & 7.18 & 4.79 & 0.23 & 1.25 & 3.33 & 9.63 & 1.46 & 3.96 & 0.89 & 1.35 \\
\hline PDL & 6.23 & 6.50 & 0.47 & 1.18 & 3.88 & 10.35 & 1.28 & 3.90 & 0.71 & 1.29 \\
\hline SKL & 6.24 & 5.25 & 0.39 & 1.24 & 3.46 & 8.24 & 0.99 & 2.61 & 0.83 & 1.19 \\
\hline SWK & 7.81 & 5.91 & 0.29 & 1.29 & 3.84 & 10.82 & 1.61 & 3.51 & 0.69 & 1.38 \\
\hline WMZ & 5.60 & 5.56 & 0.36 & 1.19 & 3.24 & 8.46 & 1.08 & 3.32 & 0.67 & 1.10 \\
\hline WLK & 6.04 & 4.79 & 0.30 & 1.26 & 3.08 & 7.71 & 1.13 & 2.80 & 0.76 & 0,98 \\
\hline ZPM & 6.13 & 5.81 & 0.34 & 1.24 & 3.99 & 9.80 & 0.99 & 3.32 & 0.84 & 1.24 \\
\hline
\end{tabular}

Source: [34];

Provinces: DLN - Dolnośląskie; KMP - Kujawsko-Pomorskie; LUB - Lubelskie; LBS - Lubuskie; LDZ - Łódzkie; MLP - Małopolskie; MAZ - Mazowieckie; OPO - Opolskie; PDK - Podkarpackie; PDL Podlaskie; POM - Pomorskie; WMZ - Warmińsko-mazurskie; SKL - Śląskie; SWK - Świętokrzyskie; WKL - Wielkopolskie; ZPM - Zachodniopomorskie.

*- Due to the fact that the density of milk varies between $1029-1033 \mathrm{~g}$ at a temperature of $20^{\circ} \mathrm{C}$ (the weight of 1 litre of milk may be within limits of 1029 and $1033 \mathrm{grams}$ ), in order to standardize calculations, it was assumed that 1 litre of milk was equal to 1.03 kilograms. In the case of eggs, it was assumed that the $\mathrm{L}$ category egg weighed $56 \mathrm{~g}$.

Because of the fact that obesity is a consequence of the longer-term imbalance between calorie requirements and supply, the consumption, measured as $1 \mathrm{~kg}$ per capita, of various types of foods in particular provinces is presented in Table 3.

The data obtained did not show a statistically-significant correlation between the number of overweight and obesity cases and the socio-economic development of the region (HDI). The study showed no dependency between the number of overweight and obesity cases in the group of adolescents and young adults, and the degree of urbanization (URBI) (Tab. 4).

No statistically significant differences were found, neither quantitative nor as percentage of obese and overweight men and women, living in urban and rural regions (Tab. 5).

The study does not explicitly indicate a relationship between the occurrence of overweight or obesity in the studied subgroups in well and poorly-developed areas (Tab. 6).

The data collected in Table 7 present a strong negative correlation between the consumption of sugar and the level
Table 4. Table of correlations: URBI, HDI, and obesity as well as overweight occurrence indicators

\begin{tabular}{lcccc}
\hline Name of Index & FOW & FOB & MOW & MOB \\
\hline \multirow{2}{*}{ HDI } & -0.4574 & 0.2893 & -0.3256 & -0.1568 \\
\cline { 2 - 5 } & $\mathrm{p}=.086$ & $\mathrm{p}=.296$ & $\mathrm{p}=.236$ & $\mathrm{p}=.577$ \\
\hline \multirow{2}{*}{ URBI } & 0.1781 & 0.5009 & -0.3911 & 0.2087 \\
\cline { 2 - 5 } & $\mathrm{p}=.525$ & $\mathrm{p}=.057$ & $\mathrm{p}=.149$ & $\mathrm{p}=.455$ \\
\hline
\end{tabular}

Source: Own calculations:

p-p-value; FOW - Female overweight; FOB - Female obesity; MOW - Male overweight; MOB - Male obesity; HDI - Human Development Index; URBI - Urbanization Index

of urbanization $(-0.710 ; \mathrm{p}=0.002)$. Moderate negative and statistically significant correlations between the level of urbanization and bread and grain product consumption $(-0.642 ; \mathrm{p}=0.007)$ and fresh milk consumption $(-0.594$; $\mathrm{p}=0.015)$ were observed. A statistically significant correlation was found between URBI and fish consumption (0.550; $\mathrm{p}=0.027)$. In the relation of HDI levels and consumption of oils and fats, a strong negative and statistically significant

Table 5. Prevalence of overweight and obesity among adolescents and young adults in urban and rural regions

\begin{tabular}{|c|c|c|c|c|}
\hline Parameter & Subgroup & Urban population [mean \pm SD] & Rural population [mean $\pm \mathrm{SD}$ ] & $\mathrm{p}$ \\
\hline \multirow{4}{*}{$\begin{array}{l}\text { Average number of overweight and obese cases in a } \\
\text { region } \\
\text { [thousand] }\end{array}$} & MOW & $52.72 \pm 28.98$ & $51.83 \pm 16.13$ & 0.101 \\
\hline & MOB & $10.81 \pm 6.37$ & $6.98 \pm 4.20$ & 0.875 \\
\hline & FOW & $27.10 \pm 14.56$ & $17.88 \pm 4.91$ & 0.483 \\
\hline & FOB & $9.51 \pm 7.16$ & $4.13 \pm 2.33$ & 0.297 \\
\hline Parameter & Subgroup & Urban population [mean] & Rural population [mean] & $\mathrm{p}$ \\
\hline Average percentage of overweight and obese & MOB & 0.44 & 0.31 & 0.560 \\
\hline [\%] & FOW & 1.14 & 0.88 & 0.092 \\
\hline & FOB & 0.32 & 0.16 & 0.668 \\
\hline
\end{tabular}

Source: Own calculations.

FOW - Female overweight; FOB - Female obesity; MOW - Male overweight; MOB - Male obesity 
Table 6. Prevalence of overweight and obesity in well and poorly-developed areas

\begin{tabular}{|c|c|c|c|c|}
\hline Parameter & Subgroup & Well-developed areas [mean \pm SD] & Poorly-developed areas [mean \pm SD] & $\mathrm{p}$ \\
\hline \multirow{4}{*}{$\begin{array}{l}\text { Number of overweight and obese cases in a province } \\
\text { [thousand] }\end{array}$} & FOW & $62.98 \pm 31.69$ & $42.01 \pm 12.92$ & 0.126 \\
\hline & FOB & $11.01 \pm 6.16$ & $8.69 \pm 5.88$ & 0.113 \\
\hline & MOW & $29.03 \pm 15.98$ & $20.56 \pm 8.41$ & 0.236 \\
\hline & MOB & $14.70 \pm 7.73$ & $3.60 \pm 1.95$ & 0.217 \\
\hline Parameter & Subgroup & Well-developed areas [mean] & Poorly-developed areas [mean] & $\mathrm{p}$ \\
\hline Percentage of overweight and obese cases in a province & FOB & 0.36 & 0.46 & 0.565 \\
\hline$[\%]$ & MOW & 0.93 & 1.22 & 0.082 \\
\hline & MOB & 0.34 & 0.22 & 0.467 \\
\hline
\end{tabular}

Source: Own calculations.

FOW - Female overweight; FOB - Female obesity; MOW - Male overweight; MOB - Male obesity.

Table 7. Correlation for average monthly consumption of selected food products per person, URBI, HDI indexes values and parameters describing obesity as well as overweight prevalence among teenagers and young adolescents in Poland

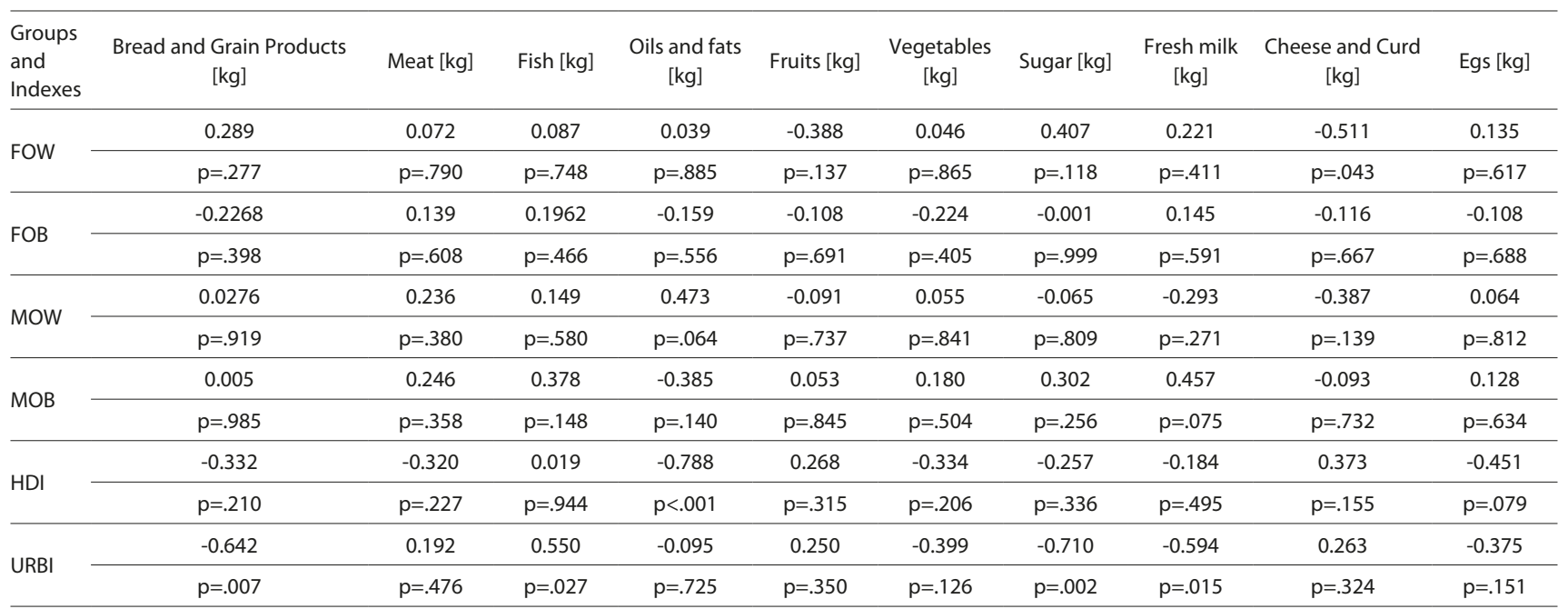

Source: Own calculations;

Source: Own calculations;
FOW - Female overweight; FOB - Female obesity; MOW - Male overweight; MOB - Male obesity; HDI - Human Development Index; URBI - Urbanization Index.

correlation was noted $(-0.788 ; \mathrm{p}<0.001)$. In the group of overweight women, a moderate negative and statistically significant correlation was noted $(-0.511 ; \mathrm{p}=0.043)$ in cheese and curd consumption.

Selected food consumption trends in Poland in the years 2003-2014 were analysed. For this purpose, the data published by the GUS in Poland were assessed [48]. It was particularly interesting to study the spatial diversity of the consumption of selected food products (Fig.1). The variability index for most products remained below $10 \%$. The only variability indices above $10 \%$ were for fresh milk (11.3\%), fish (15.8\%) and sugar (18.8\%); however, the differences expressed by these values were insignificant.

The variability indices of selected products consumed represented in Figure 1 are characterized in most cases by a certain stability. A significant increase of the variability index for sugar consumption is recorded. However, low values in the variability index of the consumption of selected products, indicate a low regional diversity of the consumption of these products in general. This means that Poland is homogeneous in this respect.

The range of the phenomena of obesity and overweight in Poland as the total mean percentage of overweight and obese people in the study age group and the level of the Human Development Index is illustrated in Figure 2.
The graphic description of the problem shows that in terms of the prevalence of obesity and overweight, Poland is not a homogeneous country. The phenomenon of overweight and obesity, measured by the total structural mean of obese and overweight people aged 15-29 in the population of the regions studied, in most cases occurs in poorly developed areas: LBS - 5.08\%, LDZ - 4.84\%, KPM - 4.58\%, PDK - 4.45\%, WMZ - 4.43\%, OPO - 4.15\%, LUB - 3.82\%, SWK - 3.78\%.

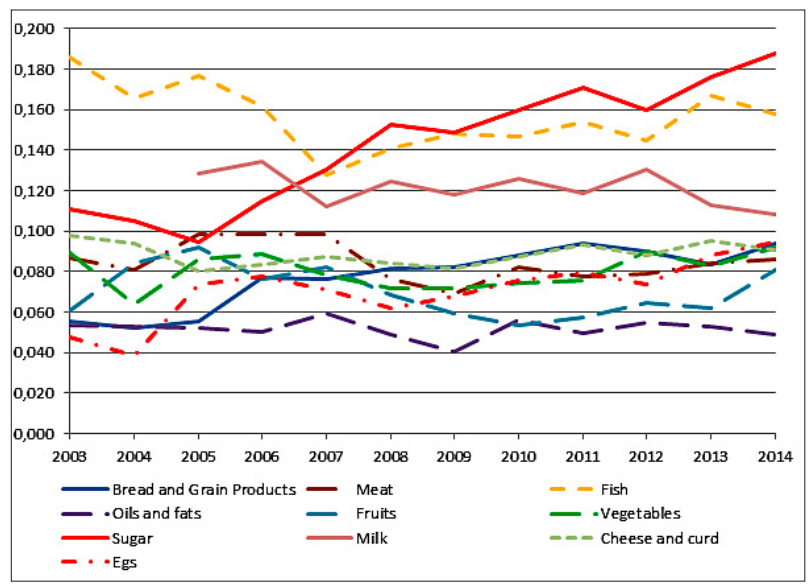

Figure 1. Variability indexes for selected foods consumed in Poland 2003-2014 
However, its high level is also noticeable in regions where the HDI exceeds the median: WLK $-4.46 \%$, PDL $-4.46 \%$, SKL - 4.19\%, POM - 3.92\%, MAZ - 3.76\% (Fig. 2).

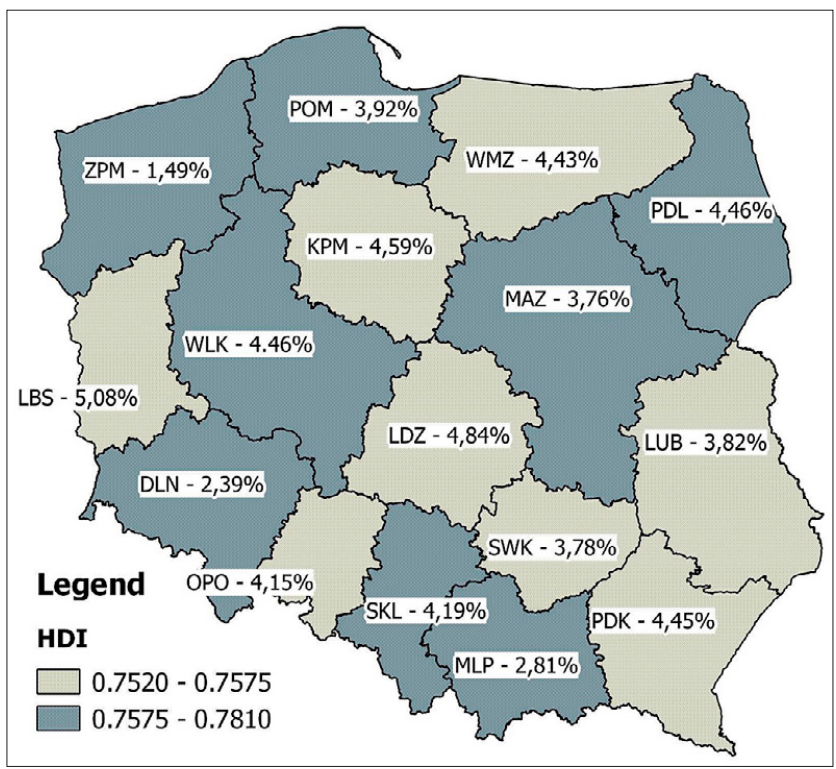

Figure 2. Socio-economic development level (as HDI value) and prevalence of obesity (as the total structural mean of overweight and obese people in the study age group in each province) in the adolescent and young adult population across Poland

\section{DISCUSSION}

Obesity is not just an aesthetic problem, it is a health hazard. The problem has become increasingly visible in all developed and many economically developing countries, including Poland. It is difficult to explain this by analysing the economic conditions alone. It appears that some other factors, e.g. cultural and historical, and even the long-lasting consequences of Prussian, Austrian and Russian annexations of Polish territory (1772-1918) should also be taken into consideration $[37,38]$.

The high values of standard deviations describing the prevalence of overweight and obesity among male and female subjects living both in urban and rural areas suggest the heterogeneity of the studied areas. The variety observed in terms of obesity and overweight, both in rural and urban areas (high SD values), may suggest that all Polish territory is heterogeneous in terms of quality of life, and this variety applies to both urban and rural areas. Although the results obtained are statistically insignificant, taking into account absolute numbers, the number of adolescents and young overweight men and women living in highly urbanized areas is slightly higher than the number of overweight men and women living in rural areas. The same can be said for structural indicators, with the exception of the urban population of overweight men. This may suggest that the urban population aged 15-29 may be treated as a risk group for obesity and overweight [39].

A similar situation occurs in the case of well and poorly developed areas. High values of standard deviation of obese and overweight people are also noticeable here, which indicates a quite significant dispersion of the studied phenomenon in well and poorly developed areas. If the internal structure of the Polish provinces (e.g. Wielkopolskie province) are taken into account, this interpretation appears to hold true logical. The heterogeneity of poorly and economically well-developed areas in terms of obesity and overweight in Poland is not an isolated case, a similar situation also occurs in several other European countries [40]. The presented study confirms results previously published by other authors dealing with the problem of excess body weight $[41,42]$.

In Poland, unlike in many countries (developed as well as many developing ones), the incidence of obesity and overweight is not closely correlated with the socioeconomic development of regions expressed by the Human Development Index value $[43,44]$. It is also difficult to observe a trend similar to that observed in some Latin American countries, where the prevalence of overweight girls decreases in well-developed regions $[23,24]$.

The results of the study did not reveal a significant correlation between the number of obese females and males and socio-economic development (HDI values (Tab. 4). The data obtained indicate that in Poland males aged 15-29 years suffer from overweight or obesity more often than females. The quantitative and structural indicators for overweight in rural and urban areas (Tab. 5) are twice as high for men than for women. Such a phenomenon is observed in many highlydeveloped countries, such as the USA, Canada $[45,46]$ and Western and Central Europe. However, in Eastern Europe, North Africa, the Middle East, the Asian-Pacific Region, as well as in Central and South America, the number of obese women exceeds the number of obese men [26, 32, 47].

Almost all over the world, obesity rates are rising, though not as rapidly or as significantly as in the USA where roughly two out of three American adults are overweight or obese (69\%), and one out of three are obese (36\%). There are indications suggesting that poor eating habits are the reason for this phenomenon $[25,48]$.

The results of this study (Tab. 3) suggest that the eating habits of men and women living in different Polish provinces are quite similar. From the results obtained, Poland is a homogeneous country in terms of its eating habits. The differences in eating habits depend more on economic status and degree of urbanization than on the region of Poland where an individual lives (Tab. 3; Tab. 7).

\section{CONCLUSIONS}

1. Both in rural and urban areas, the differences between quantitative and structural indicators for overweight and obese subgroups are not statistically significant.

2. The study did not confirm a statistically significant relationship between the prevalence of overweight or obesity and the socio-economic development of regions expressed by the Human Development Index.

3. The results of the study indicate existing dependencies of the consumption of some of selected products, especially sugar and bread and grain products, in respect to the level of urbanization.

\section{Conflicts of Interests}

The authors declare they have no conflict of interests. 


\section{REFERENCES}

1. Tatoń J, Czech A, Bernas M. Zaburzenia endokrynne tkanki tłuszczowe w patogenezie otyłości. In: Tatoń J, Czech A, Bernas M. Otyłość. Zespół metaboliczny, PZWL, Warszawa; 2007. p. 138-147.

2. Silventoinen K, Rokholm B, Kario J, Sorensen TI. The genetic and environmental influences on childhood obesity: a systematic review of twin and adoption studies. Int J Obes. 2010; 34(1): 29-40.

3. Townshend T, Lake A. Obesogenic environments: current evidence of the built and food environments. Perspect Public Health. 2017; 137(1): 38-44.

4. Spigel K, Tasali E, Penev P, VanCauter E. Brief communication: sleep curtailment in healthy young men is associated with decreased leptin levels, elevated ghrelin levels and increased hunger and appetite. Ann Intern Med. 2004; 141(11): 846-850.

5. Boyland EJ, Whalen R. Food advertising to children and its effects on diet: review of recent prevalence and impact data. Pediatr Diabetes. 2015; 16(5): 331-337.

6. Hruby A HF. The Epidemiology of Obesity: A Big Picture. Pharmacoeconomics. 2015; 33(7): 673-689.

7. Kuźbicka K, Rachon D. Bad eating habits as the main cause of obesity among children. Pediatr Endocrinol Diabetes Metab. 2013; 19(3): 106-110.

8. Droń I, Wrzołek K, Klatka M. Otyłość olbrzymia u 2,7 letniego chłopca - czy to rzeczywiście problem endokrynologiczny? - opis przypadku. Endokrynol Ped. 2014; 3(48): 71-78.

9. Suliburska J, Bogdański P, Pupek-Musialik D, Głód-Nawrocka M, Krauss H, Piątek J. Analysis of lifestyle of young adults in the rural and urban areas. Ann Agric Environ Med. 2012; 19(1): 135-139.

10. Engler-Stringer R, Shah T, Bell S, Muhajarine N. Geographic access to healthy and unhealthy food sources for children in neighborhoods and from elementary schools in a mid-sized Canadian city. Spat Spatiotemporal Epidemiol. 2014; 11: 23-32.

11. Oliver LN, Hayes MV. Neighborhood socio-economic status and the prevalence of overweight Canadian children and youth. Can J Public Health. 2005; 96(6): 415-420.

12. Kinara S, Nelder RP, Lewendon GJ. Deprivation and childhood obesity: a cross-sectional study of 20,973 children in Plymouth, United Kingdom. J Epidemiol Community Health. 2000; 54(6): 456-460.

13. Lundborg P, Nystedt P, Rooth DO. Body size, skills, and income: evidence from 150,000 teenage siblings. Demography. 2014 Oct; 51(5): 1573-1596.

14. Atella V, Kopinska J. Body Weight, Eating Patterns, and Physical Activity: The Role of Education. Demography. 2014; 51(4): 1225-1249.

15. Dietz WH. Overweight in childhood and adolescence. N Engl J Med. 2004; 350(9): 855-857.

16. Calle EE, Rodriguez CK, Walker-Thurmond J, Thun M. Overweight, obesity, and mortality from cancer in a prospectively studied cohort of U.S. adults. N Engl J Med. 2003; 348(17): 1625-1638.

17. August GP, Caprio S, Fennoy I, Freemark M, Kaufman FR, Lustig $\mathrm{RH}$, et al. Prevention and treatment of pediatric obesity: an endocrine society clinical practice guideline based on expert opinion. J Clin Endocrinol Metab. 2008; 93(12): 4576-4599.

18. Mehta NK, Chang VW. Mortality attributable to obesity among middleaged adults in the United States. Demography. 2009; 46(4): 851-872.

19. Hammond RA, Levine R. The economic impact of obesity in the United States. Diabetes Metab Syndr Obes. 2010; 3: 285-295. doi: 10.2147/ DMSOTT.S7384

20. Piekarzewska M, Wieczorkowski R, Zajenkowska-Kozłowska A. Stan zdrowia ludności Polski w 2014 roku. GUS, Warszawa, 2016.

21. Jarosz, M. Zasady prawidłowego żywienia dzieci i młodzieży oraz wskazówki dotyczące zdrowego stylu życia. Instytut Żywności Żywienia, Warszawa, 2008.

22. Suder A, Janusz M, Jagielski P, Glodzik J, Palka T, Cison T, et al. Prevalence and risk factors of abdominal obesity in polish rural children. Homo. 2015; 66(4): 357-368.

23. daVeiga GV, daCunha AS, Sichieri R. Trends i overweight among adolescents living in the poorest and richest regions in Brazil. Am J Public Health. 2004; 94(9): 1544-1548.

24. Niehues JR, Gonzales AI, Lemos RR, Bezerra PP, Haas P. Prevalence of Overweight and Obesity in Children and Adolescents from the Age Range of 2 to 19 Years Old in Brazil. International Journal of Pediatrics. 2014; 583207. doi: 10.1155/2014/583207

25. Flegal KM, Carroll MD, Kit BK, Ogden CL. Prevalence of obesity and trends in the distribution of body mass index among US adults, 1999-2010. JAMA. 2012; 307(5): 491-497.

26. Ng SW, Zaghloul S, Ali HI, Harrison G, Popkin BM. The prevalence and trends of overweight, obesity and nutrition-related non-communicable diseases in the Arabian Gulf States. Obes Rev. 2011; 12(1): 1-13.
27. Hilpert M, Brockmeier K, Dordel S, Koch B, Weiß V, Ferrari N, et al. Sociocultural Influence on Obesity and Lifestyle in Children: A Study of Daily Activities, Leisure Time Behavior, Motor Skills, and Weight Status. Obes Facts. 2017; 10(3): 168-178.

28. Agne AA, Daubert R, Munoz ML, Scarinci I, Cherrington AL. The cultural context of obesity: exploring perceptions of obesity and weight loss among Latina immigrants. J Immigr Minor Health. 2012; 14(6): 1063-1070.

29. Ball K, Crawford D. The role of socio-cultural factors in the obesity epidemic. In: Crawford D, Jeffery RW, Ball K, Brug J. Obesity Epidemiology: From Aetiology to Public Health. ed.: Published to Oxford Scholarship Online; 2011. https://www.oxfordscholarship. com/view/10.1093/acprof:oso/9780199571512.001.0001/acprof9780199571512-chapter-8 (access: 2017.12.08).

30. Hales CM, Fryar CD, Carroll MD, Freedman DS, Aoki Y, Ogden CL. Differences in Obesity Prevalence by Demographic Characteristics and Urbanization Level Among Adults in the United States, 2013-2016. JAMA. 2018; 319(23): 2419-2429.

31. Ekezje J, Anyanwu E, Danborno B, Anthony U. Impact of urbanization on obesity, anthropometric profile and blood pressure in the Igbos of Nigeria. N Am J Med Sci. 2011; 3(5): 242-246. doi: 10.4297/ najms.2011.3242

32. Ziraba AK, Fotso JC, Ochako R. Overweight and obesity i urban Africa: A problem of the reach or the poor? BMC Public Health. 2009; 9: 456. doi: 10.1186/1471-2458-9-465.

33. GUS. Produkt krajowy brutto i wartość dodana brutto według województw i podregionów w latach 2010-2015. GUS, Warszawa, 2017.

34. GUS. Local Data Bank. Domestic deliveries and consumption of selected consumer goods per capita in 2014. http://stat.gov.pl/bdl/ app/dane_podgrup.hier?p_id=760060\&p_token=-715577720 (access: 2019.02.16).

35. Neumayer E. The human development index and sustainability - a constructive proposal. Ecological Economics. 2001; 39(1): 101-114.

36. UNDP. Human Development Report. Concept and Measurement of Human Development. UNDP, 1990.

37. Żyromski M. Nawyki żywieniowe w dziejach rodziny polskiej. Roczniki Socjologii Rodziny. 2003; XV: 95-112.

38. Grosfeld I, Zhuravskaya E. Persistent effects of empires: Evidence from the partitions of Poland. PSE, Paris, 2013.

39. Hill JL, You W, Zoellner JM. Disparities in obesity among rural and urban residents in a health disparate region. BMC Public Health. 2014; 14: 1051. https://doi.org/10.1186/1471-2458-14-1051 (access: 2019.07.30).

40. Lissner L, Wijnhoven TMA, Mehlig K, Sjöberg A, Kunesova M, Yngve A, Petrauskiene A, Duleva V, Rito AI, Breda J. Socioeconomic inequalities in childhood overweight: heterogeneity across five countries in the WHO European Childhood Obesity Surveillance Initiative (COSI2008). Int J Obes (Lond). 2016; 40(5): 796-802.

41. Khan LK, Bowman BA. Obesity: a major global public health problem. Annu Rev Nutr. 1999; 19: 13-17.

42. James PT, Leach R, Kalamara E, Shayeghi M. The worldwide obesity epidemic. Obes Res. 2001; 9 Suppl 4: 228S-233S.

43. Dinsa GD, Goryakin Y, Fumagalli E, Suhrcke M. Obesity and socioeconomic status in developing countries: a systematic review. Obes Rev. 2012; 13(11): 1067-1079.

44. McLaren L. Socioeconomic status and obesity. Epidemiol Rev. 2007; 29(1): 29-48.

45. The Henry J. Kaiser Family Foundation. The Henry J. Kaiser Family Foundation. http://kff.org/other/state-indicator/adultoverweightobesity-rate-by-gender/ (access: 2015.05.01).

46. Employment and Social Development Canada (ESDC). http://wellbeing.esdc.gc.ca/misme-iowb/.3ndic.1t.4r@-eng.jsp?iid=6 (access: 2015.05.01).

47. Cheung L, Hu F. Adult obesity. https://www.hsph.harvard.edu/obesityprevention-source/obesity-trends/obesity-rates-worldwide/ (access: 2019.02.16).

48. Centers for Disease Control and Prevention. Strategies to Prevent Obesity and Other Chronic Diseases: The CDC Guide to Strategies to Increase the Consumption of Fruits and Vegetables Atlanta: US Department of Health and Human Services, 2011.

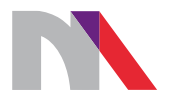

Ministry of Science and Higher Education

Republic of Poland

Generation of the DOI (Digital Object Identifier) - task financed under the agreement No. 618/P-DUN/2019 by the Minister of Science and Higher Education 